\title{
Relevance of supply chain dominance: A global perspective
}

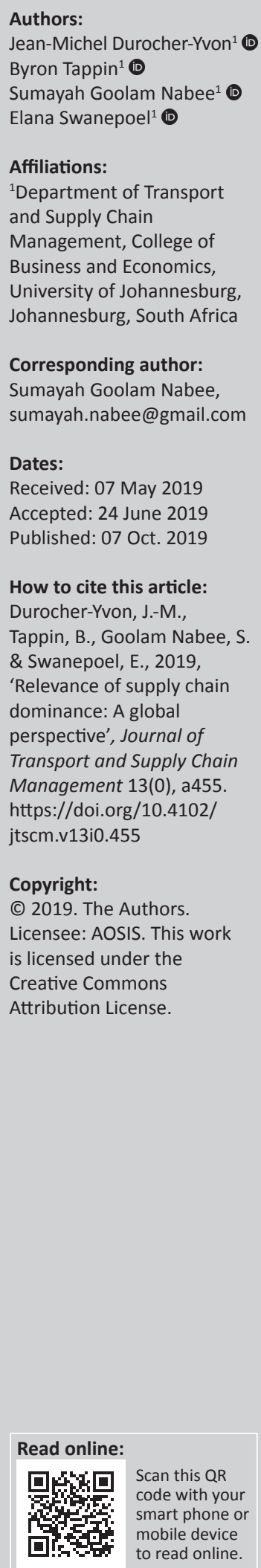

Background: The increasing pressure on businesses to remain competitive has made dominant practices more prevalent, particularly in the automotive and retail industries. Financial, exclusionary and exploitative practices seem to be the main occurrences in the global supply chain when analysing dominant behaviours.

Objectives: The study explores the global existence of dominant supply chain behaviour and the type of dominant supply chain practices to which smaller supply chain affiliates are subjected.

Method: Because of the sensitive nature of the topic, it was not possible to collect primary data. Therefore, secondary qualitative data sourced from surveys, journal articles, news reports, websites, governmental publications and academic reports were analysed and quantitised.

Results: A total of 60 cases of dominance were reported in regions across the globe, with Europe and the United States experiencing the most. Although companies in African and Asian markets experienced dominance, the reporting of these incidents seems to be limited.

Conclusion: It emerged that dominance is more prevalent in certain industries such as the automotive and retail sectors, mainly through resented practices. Furthermore, small firms that experience bullying have either had to close down or conform to the requirements of the bullying firm to maintain its operations.

Keywords: supply chain dominance; global; United States; Europe; Africa; Asia; financial, exclusionary and exploitative practices; resented practices; automotive; retail.

\section{Introduction}

\section{Relationships in supply chains}

A dynamic relationship exists between each member of the supply chain requiring a holistic approach for a better understanding of the ever-changing needs of today's customers (Arshinder, Kanda \& Deshmukh 2011). A supply chain encompasses several partners in different locations, either on a national or international scale. The management of these delicate connections is the least understood aspect within the supply chain management field (Mocke, Niemann \& Kotze 2016). Buyer-supplier relationships must be developed as the success of a supply chain is limited to the performance of its weakest link (Beske, Land \& Seuring 2014).

\section{Relationships between supply chain partners}

Supply chain members cannot compete successfully as individuals but can as a connected unit (Arshinder et al. 2011). The connectivity of members has created a dependency between the partners in the supply chain, reliant on information and physical flows, both upstream and downstream. The increasing dependency has been influenced by technological innovations, globalisation and the changing economic landscape (Arshinder et al. 2011). Integrated technological innovations allow supply chain members to connect and coordinate with all partners. These technological innovations have contributed to the globalisation of supply chains and partners, enabling smaller companies to compete on a global scale. However, because of their smaller market share, the latter are more susceptible to economic changes.

Economic changes such as low commodity prices, low business confidence as well as low consumer confidence may cause problems, both for the organisation as well as the relationship between supply chain members (Smith 2015). The physical connectedness, being the most visible part of the supply chain, encompasses the production, movement and subsequent storage of 
products. However, the supply chain is also connected through the passing of information to all members. This flow assists partners in determining and organising their longterm goals and objectives as well as their day-to-day flow of goods (North Carolina State University 2011).

Dynamic relationships are key to the success of any integrated supply chain as the closer the relationships are, the greater the satisfaction of members (Deci \& Ryan 2014). This leads to satisfaction and cooperation between members (Benton \& Maloni 2005). The satisfaction of suppliers is greatly influenced by the feeling of equity in the relationship despite the different power structures within the relationship (Benton \& Maloni 2005). Trust plays a critical role in relationship management, as without trust, the dynamic relationship may fall apart leading to risks in the supply chain (Hines \& Samuel 2004). However, trust between partners is developed over a period of time (British Institute of Facilities Management 2015).

\section{Pitfalls faced by supply chain partners}

Supply chain coordination poses several challenges for the effective operation and cooperation of supply chain members, such as cost, quality, competition and the management of relationships between all members (Li et al. 2006). Increased competition has resulted in a greater need for lower prices and higher quality products for the customer (Sweeney 2011). Thus, relationship management is an integral part of supply chains as they are most effective when partners collaborate and are involved (Coyle et al. 2013). However, because of the individualistic nature and unique goals of the supply chain members, conflicts arise.

\section{Supply chain dominance}

In today's business world, market share and market dominance have played an important role in shaping businesses. The dominance by a market leader in the supply chain is no longer only seen from the perspective of market share dominance but also as the manipulation and domination of suppliers by larger firms (Babilonia n.d.).

The use of dominance in supply chains is not a new concept. In 1958, Raven and French (cited by Barber 2011) explored inter-firm dominance and developed five power bases contributing to one partner dominating another in the supply chain (Barber 2011), namely legitimate, reward, expert, referent and coercive power. However, 6 years later, Raven added an additional power base, namely informational power (Raven 2008). Legitimate power is when a person has the right to make a demand. Reward is offered when one partner is compliant with the demand and is therefore compensated. Expert power is based on a person's high skill level and knowledge. Referent power refers to the perceived worthiness and respect of others in the supply chain. Coercive power base states that a member of the supply chain can be punished for non-compliance of demands. Lastly, informational power is the ability to control the access to information (Raven 2008).
According to Benton and Maloni (2005:2), 'firms with the bargaining power have little if any reason to yield control or to withhold exercise of such power'. Therefore, firms with substantial power may consider win-win alliances unnecessary, as they can achieve profitability and effectiveness through control of their suppliers (dependents).

Supply chain dominance is not a clearly defined term. For purposes of this study, it is defined as the influence, either positive or negative, that a participant in the supply chain has over partners operating in the same supply chain. This research focuses on the negative aspect of supply chain dominance as very little research has focused on it.

Dominance in the supply chain is experienced through different types of practices, such as financial, exclusionary and exploitative practices. Financial practices consist of several resented practices including pay-to-stay, long payment terms, late payment, prompt payment discounts and respective discounting (Green 2014).

Exclusionary practices are those which restrict organisations from supplying certain downstream customers or competitors through discounts or incentives. Such practices may be anticompetitive in nature, resulting in smaller firms exiting the market, while restricting new firms from entering the market (Zietsman \& Coetser 2017). In addition, exclusionary practices can keep competitors weak or prevent them from expanding operations. However, in the short term, it is difficult to differentiate exclusionary practices from tough competition. An example of this is predatory pricing whereby firms offer more goods at lower prices (United Nations Conference on Trade and Development [UNCTAD] 2008). Although, in the short term, consumers benefit from such practices and it appears to be merely aggressive competitive practices, in the long run, competing firms are excluded, allowing the dominating firm to lower prices further as well as reducing product quality (UNCTAD 2008).

Exploitative practices occur when dominant firms increase prices, decrease variety or quality of products or act in a manner that is solely beneficial to itself and that they would not be able to achieve in a competitive setting (UNCTAD 2008).

Abusive practices can be divided into pricing and nonpricing strategies, involving the refusal to interact or supply other firms. Although businesses are free to choose their business partners, it can be viewed as anti-competitive as it may exclude or discriminate against other firms within the market (UNCTAD 2008). Moreover, the effects of these resented practices are magnified in developing countries because of a larger sector of local markets being isolated from trade liberalisation measures; limited access to vital inputs as well as restricted distribution channels; greater dependence on imports, in terms of basic industrial inputs, and/or exports, in terms of growth; frequent occurrences of administrative or institutional barriers to imports; and lastly weak capital markets (OECD 2003). 
According to the Federation of Small Businesses (FSB), supply chain bullying affects one out of five small companies (Matthews 2014). In the United Kingdom, the FSB found that $17 \%$ of small businesses have been victims of bullying by larger firms (Ruddick 2014). This statistic is portrayed in several examples. Heinz doubled the time taken to settle supplier invoices by increasing payment times from 45 to 97 days (Sunderland 2015). Anheuser-Busch InBev (ABInBev), the manufacturer of Stella Artois and Boddingtons, takes over 4 months to pay their suppliers. Marks and Spencer seem to be bullying by increasing their supplier payment terms from 60 to 75 days, which could negatively affect the suppliers' cash flow. Tesco demanded that their suppliers decrease their prices of goods because of slacking commodity prices, threatening to withdraw products if suppliers refused (Williams 2015). In 2014, in the United Kingdom, late payments amounted to $£ 46$ billion (Sunderland 2015).

Furthermore, in the automotive industry, bullying seems to be experienced by suppliers. The Volkswagen (VW) Dieselgate scandal (The Drive 2015a) has been the most destructive in the history of the automotive industry. Volkswagen illegally installed software into their fourcylinder TDi engines to avoid smoke standards specified by the United States Clean Air Act. This software allowed them to conceal emissions of nitrogen oxide which causes smog, asthma and lung cancer. In September 2015, VW faced penalties of $\$ 37500.00$ per vehicle with approximately 482000 vehicles - including those supplied to Audi - under investigation for the Dieselgate allegation. This action by VW implicated upstream and downstream supply chain partners. Apart from a resulting drop in sales, vehicles had to be recalled and repaired - these actions affected both the VW suppliers and dealers. Volkswagen pleaded guilty to the allegations and agreed to pay US $\$ 4.3 \mathrm{bn}$ because of Dieselgate (Mail Online 2017). Fiat-Chrysler and Renault have been included in similar emissions allegations. Renault has insisted that their engines comply with French and European regulations (Agence France-Presse 2017).

\section{Contribution of the study}

The research problem is that the increasing pressure on businesses to remain competitive has made dominant practices more prevalent, particularly in the automotive and retail industries. Only a few studies have investigated the relationship dominance in the supply chain and the effect that this has on the overall success of the supply chain (Babilonia n.d.; Barber 2011; Schleper, Blome \& Wuttke 2015). From a literature perspective, the dominance a supply chain market leader has on several other smaller suppliers found in this industry is analysed. The dynamic relationships between manufacturers, distributors and customers leading to the overall success of the supply chain, from an end-to-end view, are investigated. The research objective was to analyse the financial, exclusionary and exploitative practices relevant to dominant behaviour in the global supply chain. From reported incidences of dominance, whether or not dominance in the supply chain occurs, why it occurs, where it is happening, the forms of dominance as well as who is affected are explored.

\section{Literature review Supply chain relationships}

Relationships in the supply chain can be either participative or directive (Akhtar \& Khan 2015). While participative relationships motivate the members to share their decisionmaking power among supply chain members, a directive relationship approach results in practices, such as uniform procedures, instructions and obligatory instructions (Akhtar \& Khan 2015). Furthermore, the latter approach does not share decision-making power among partners. In contrast, partnerships found in the agricultural industry share information among the partners, providing essential tools to improve coordination in the industry, resulting in improved partner productivity (International Fund for Agriculture Development 2013).

Power is found at the core of business-to-business relationships and is often seen as being unethical. Within buyer-supplier relationships, two subsectors can be identified, namely the captive buyer and captive supplier (Burt, Dobler \& Starling 2003). In a captive supplier relationship, the supplier invests into the buyer's business; however, at the risk of no assurance that the supplier will gain back what they have invested. In a captive buyer relationship, the buyer is restricted to one supplier despite the supplier having several buyers (Burt et al. 2003). Subsequently, these relationships are of a dynamic nature, influenced by the power structure that has developed within the relationship as well as the ethical climate in which these affairs exist (Schleper et al. 2015). To differentiate normal business practices from unethical and manipulative behaviours can be achieved through the examination of the relationship from an economic viewpoint, overserved as liberal transactions for profit maximisation, in conjunction with a moral viewpoint. This is based on Thomas Aquinas theory of 'just and fair prices', aimed at achieving equilibrium within transactions (Schleper et al. 2015).

\section{Economic and moral perspectives of contractual relationships}

It is difficult to identify ethical problems from an economic standpoint as transactions and contracts undertaken by organisations are on a voluntary basis aimed at improving the individual standards of both parties, thus being equally beneficial (Schleper et al. 2015). With both representatives informed of the conditions of such proceedings and a voluntary agreement reached, the transaction is classified as fair. Moreover, even if both parties act in terms of their own self-interests, in accordance with the rules of voluntary trade, these transactions will still be deemed as ethical as selfinterested activities synchronise, adding to the promotion of the common good for society (Simpson 2009). Contrastingly, transactions are only identified as unethical if a supplier is prevented from acting in accordance with their own 
self-interests thus benefiting the buying organisation. In such an instance, the buyer coerces a supplier as well as suppresses information crucial to proceedings in a deceptive manner (Schleper et al. 2015).

The moral perspective includes honesty and integrity, climaxing into the culmination of justice (Woiceshyn 2011). Justice is derived from self-interest whereby objective treatment of others provides deserved exchanges through equal interactions of value. Thus, through the pursuit of self-interests, firms realise their dependence on other organisations. However, if there is an absence of apparent justice, the collaboration will cease among the firms, even if the transactions are mutually beneficial. Furthermore, supplier exploitation is at all times, an act of gaining benefits, yet it is difficult to determine whether the exploitation that is exercised is just or unjust (Schleper et al. 2015). Thus, Mayer (2007) reasoned that immoral manipulation occurs when the exploiting firm gains an advantageous position at the expense of the exploited firm; whereby the latter firm is unable to benefit accordingly within the requirements of just practices. It can be concluded that although contracts have economic and moral boundaries, the individual actions of organisations cannot be regulated.

\section{Exploitation of suppliers by dominant organisations}

Buyer-supplier relationships are undergoing greater scrutiny as the interest of stakeholders on organisational social responsibility and ethical matters increases. This has resulted in a greater public awareness of dominant organisations that have been accused of abusing their power over suppliers (Schleper et al. 2015). The mistreatment of suppliers is not exclusive to one industry. It is a widespread practice in various industries and markets, such as the retail, automotive and consumer electronics market. Dell Inc. (Dell) with its ultra-lean, high-speed business model, integrating just-intime (JIT) mechanisms across their entire global operation, has developed extreme dependencies on their suppliers. Thus, constant communications are needed with their suppliers from the United States, Malaysia, Taiwan and China as well as minimisation of finished goods in order to achieve this JIT model (Breen 2004). Such risky business procedures have enabled Dell to develop into one of the fastest, most hyper-efficient originations in the world. However, in order to fully assimilate into this state of maximum efficiency and effectiveness, a new finance model had to be adopted, whereby customer credit card or online transaction payments are able to be received immediately by Dell. Conversely, Dell will only pay their suppliers to such transactions, 36 days after payment has been received. This has enabled Dell to ensure that their operating costs are financed by their suppliers, through a negative 36-day cashconversion cycle (Breen 2004). This business model places extreme accumulating pressures on their suppliers to perform at increasing levels, whereby Dell monitors such performance through metric-based measurements placed on their supplier's ability to compete on cost, technology, supply predictability and service. This, in turn, minimises supplier longevity with Dell, making competition among suppliers insurmountable, with even top achieving suppliers barely able to match Dell's exceptionally high standards. Yet, even when Dell is accused of promoting unethical business practices, they continue with this practice and even view it as acceptable (Breen 2004).

In South Africa, tea giant Rooibos Limited has been accused of dominant practices by the Competition Commission after Khoisan tea laid a complaint in 2015 (Crotty 2017). The commission stated that Rooibos Limited has utilised its competitive position in the market to prevent the growth of their competitors, which has resulted in Rooibos having to pay an administrative penalty equalling $10 \%$ of their annual turnover. Although Rooibos Limited controls $70 \%$ of the market, the Deputy Competition Commissioner said that dominant firms have a responsibility to not limit the competition and were concerned with Rooibos Limited's continuous dominant conduct as it negatively affects the growth of the agro-processing industry in South Africa (Crotty 2017).

With unfair transactions like retrospective alterations to formal contracts, as well as financial exploitation, investments are undertaken to continue operating on a supplier-level, identified as 'pay-to-stay' arrangements (Ruddick 2014). Such tactics were implemented by Premier Foods, and with Tesco involved in an accounting scandal amounting to $£ 263$ million, promises to repair supplier relations are now prominent. However, further schemes used by dominant firms have been identified by the FSB and include delayed payments to suppliers, self-given discounts for early on-time payments to suppliers as well as the generation of discounts on amounts owed to suppliers (Ruddick 2014).

Additionally, supermarkets in the United Kingdom have found a new way of delaying payments to suppliers, allowing them to gain more dominance as well as bully the suppliers at the supplier's expense (Steiner 2015). This dominance is evident when supermarkets team up with banks such as Lloyd's, HSBC and the Royal Bank of Scotland. Originally, the suppliers were paid after 30 or 60 days; however, the supermarkets are now extending the payment terms to 90 days. If the supplier requires the funds in a shorter time period, the bank will offer a payment scheme whereby they can be paid in the form of a loan provided by the bank (Steiner 2015). This loan is provided with an attached interest rate of approximately $1.2 \%$. The supplier is now in-effect paying additional funds to receive a payment for goods delivered. Because of the interest charged, the supplier achieves lower revenue compared to when the payment terms were 30 or 60 days. This ultimately affects the suppliers' overall profits as they may experience cash flow difficulties and increased financing costs (Steiner 2015).

Consequently, the FSB has proposed that supply chain bullying may be more prominent among supplier interactions with multinational organisations. A 2014 survey of 2500 FSB members revealed that one out of five (17\%) had faced supply 
chain bullying in the preceding 2 years (Axis Telecoms 2014). Small businesses are no longer able or prepared to be subjected to such stringent practices as it denies them access to indispensable capital. Thus, a breaking point is imminent that could result in an irreconcilable relationship between buyers and suppliers that will hinder the entire operation of a supply chain. This growing issue has pressurised politicians to respond, providing solutions to ease this crisis, such as standardising payment arrangements (Axis Telecoms 2014). The United Kingdom government has recognised the issues and enforced compulsory report generation by large companies on their payment practices, payment terms, average time taken to pay, proportion of invoices paid within specified periods and invoices paid beyond stated terms, and lastly, late payments generating interest that has been settled or is still outstanding (Cavano 2015).

However, this is not the first intervention to impose an ethos of timely ethical payments, with Prompt Payment Code being implemented in the United Kingdom, encouraging organisations to voluntarily reform to its methods of 30-day payment terms, with a maximum of 60 days. Thus, firms signed up to this code can be examined by a compliance board to ensure that business behaviours are within its stated rules and procedures (Cavano 2015).

A report released by the United Nations Conference on Trade and Development (UNCTAD) states that abuse of dominance is a problematic area of competition law and policy stated by competition authorities, as analysing the effects of resented practices can be difficult and time-consuming (UNCTAD 2008). This is because of this form either aiding or hindering the progress towards competition objectives. The report identified serious problems of abuse of dominance faced by authorities (UNCTAD 2008). Thus, competition authorities have increased their efforts in fighting anti-competitive practices in their respective markets, resulting in dominant firms behaving with greater caution as transgressions against their respective laws have serious consequences. The different authorities in the different countries usually have varying competition law objectives, definitions and ways of assessing dominance, ideas of what constitutes abusive practices as well as what markets are excluded from the application of these laws (UNCTAD 2008).

Consequently, the increasing involvement from government and organisations alike has gained the attention of the media (Institute of Business Ethics 2013). This has driven the global media institutions to conduct investigations of their own, exposing various high-profile organisations across multiple sectors of being implicated in such unethical behaviour (Cavano 2015). A number of cases of supplier squeezing by dominant firms have been reported in the media (Table 1). The offences occurred in the automotive, aviation, retail and consumer electronics industries and included companies such as General Motors (GM), Boeing, Amazon and Apple. Therefore, this exposes that supply chain dominance is dispersed among various industries.

TABLE 1: Supplier squeezing in the media, selected headlines.

\begin{tabular}{|c|c|c|c|c|}
\hline Industry & Case & Headline & Accusation by media & Magazine (year) \\
\hline Automotive & GM & $\begin{array}{l}\text { GM's supplier squeezing days gave birth to } \\
\text { flawed models }\end{array}$ & $\begin{array}{l}\text { 'China-cost' approach: suppliers have to match } \\
\text { the costs of their Chinese competitors to be } \\
\text { further considered }\end{array}$ & Bloomberg (2014) \\
\hline Aviation & Boeing & $\begin{array}{l}\text { McNerney: Boeing will squeeze suppliers and } \\
\text { cut jobs }\end{array}$ & $\begin{array}{l}\text { 'No-fly list': if suppliers do not reduce prices, } \\
\text { they lose future business }\end{array}$ & Seattle Times (2013) \\
\hline Beverage & Anheuser-Busch & $\begin{array}{l}\text { A-B suppliers will have to wait longer to } \\
\text { get paid }\end{array}$ & $\begin{array}{l}\text { Extension of payment terms from } 30 \text { days to } \\
130 \text { days }\end{array}$ & $\begin{array}{l}\text { St. Louis/Post-Dispatch } \\
\text { (Missouri) (2009) }\end{array}$ \\
\hline $\begin{array}{l}\text { Consumer } \\
\text { electronics }\end{array}$ & Apple & $\begin{array}{l}\text { Apple reportedly squeezing supplier to stop } \\
\text { building MacBook Air clones from Asus }\end{array}$ & $\begin{array}{l}\text { Supplier will lose business if it continues to produce similar } \\
\text { product for a competitor }\end{array}$ & Apple Insider (2012) \\
\hline Retailer & Amazon & $\begin{array}{l}\text { Writers caught in the middle of Amazon- } \\
\text { Hachette battles - Retailing giant's efforts to } \\
\text { pressure a publisher draw claims of bullying }\end{array}$ & $\begin{array}{l}\text { Discourage customers to buy products from a } \\
\text { specific supplier by using aggressive means }\end{array}$ & $\begin{array}{l}\text { International New York Times } \\
\text { (2014) }\end{array}$ \\
\hline Retailer & Amazon & Let's Count all the Ways Amazon's a Big Bully & $\begin{array}{l}\text { Supplier claims at court four aspects of misconduct by } \\
\text { the buying firm: patent infringement, unfair competition; } \\
\text { intentional interference with contracts and economic } \\
\text { relations, false advertising }\end{array}$ & The Wire (2011) \\
\hline Retailer & Coles & $\begin{array}{l}\text { ACCC takes action against Coles over alleged } \\
\text { treatment of suppliers }\end{array}$ & $\begin{array}{l}\text { Buying firm allegedly used unfair tactics to gain price } \\
\text { decreases by taking advantage of superior buyer power, } \\
\text { Suppliers were required to agree to new complex rebate } \\
\text { program without sufficient time to assess al involved costs }\end{array}$ & Sydney Morning Herald (2014) \\
\hline Retailer & Laura Ashley & $\begin{array}{l}\text { Laura Ashley accused of bullying over } \\
\text { price-cut demand to suppliers }\end{array}$ & $\begin{array}{l}\text { Demanding of } 10 \% \text { price reduction also on offers already } \\
\text { placed in the past }\end{array}$ & Telegraph (2013) \\
\hline Retailer & Tesco & $\begin{array}{l}\text { Tesco squeezes suppliers with } 40 \% \text { rebate } \\
\text { demand }\end{array}$ & $\begin{array}{l}\text { Attempt to impose a fee of up to } 40 \% \text { on contracts already } \\
\text { agreed on }\end{array}$ & Daily Mail (2009) \\
\hline Retailer & Tesco & $\begin{array}{l}\text { Tesco under investigation over suspected } \\
\text { supplier mistreatment }\end{array}$ & $\begin{array}{l}\text { Delayed payments to suppliers and demanded payments } \\
\text { from businesses for more prominent positioning of their } \\
\text { products within stores }\end{array}$ & The Telegraph (2015) \\
\hline Retailer & Sainsbury & Sainsbury puts squeeze on its suppliers & Extension of payment terms from 21 to 49 days & The Standard (2008) \\
\hline Retailer & Wal-Mart & The Wal-Mart Squeeze & $\begin{array}{l}\text { Wal-Mart reduces margins of suppliers based on power } \\
\text { imbalance }\end{array}$ & Forbes (2007) \\
\hline Retailer & Woolworths & $\begin{array}{l}\text { Woolworths accused of squeezing } \\
\text { manufacturers }\end{array}$ & $\begin{array}{l}\text { "Suppliers have told that Woolworths has given scores of } \\
\text { suppliers } 2 \text { weeks to cut their prices by up to } 10 \% \text { or have } \\
\text { their products pulled from the supermarket's shelves" }\end{array}$ & Sidney Morning Herald (2012) \\
\hline Vehicles & Caterpillar & Is Caterpillar bullying its suppliers? & $\begin{array}{l}\text { "Cat's new stinginess has been enough to drive at least one } \\
\text { suburban Chicago supplier out of business" }\end{array}$ & Crain's Chicago Business (2013) \\
\hline
\end{tabular}

Source: Schleper, M.C., Blome, C. \& Wuttke, D.A., 2015, 'The dark side of buyer power: Supplier exploitation and the role of ethical climates', Journal of Business Ethics 140(1), 98. https://doi. org/10.1007/s10551-015-2681-6.

GM, General Motors; ACCC, Australian Competition and Consumer Commission. 


\section{Supply chain dominance in the automotive industry}

Although dominant practices appear in numerous sectors, it seems to be more prevalent in the automotive industry, which is facing a challenging period. This is seen through the growth of the shared economy, and the drive towards autonomous vehicles through the partnerships of disruptive technological companies (Euler Hermes 2017). Furthermore, within this industry, manufacturers must maintain a global presence to assist in the longevity of the sector (Euler Hermes 2017).

With regard to the VW Group diesel emissions scandal, Robert Bosch $\mathrm{GmbH}$ (Bosch) was accused of aiding VW in their operations to hide the existence of the emission cheating software. Without admitting to any transgressions or liability, the world's largest vehicle component supplier agreed to pay \$327.5m (Berlin 2017). With both VW and Bosch eager to put this diesel scandal behind them, it may point to strategic collaboration or coercion as this is how players within the supply chain exert their power.

In the early 1990s, such abusive power has been identified in the past, linked to José Ignacio López de Arriortúa, the vice president of purchasing at GM as he ushered in a new era of supplier exploitation (Henke, Yeniyurt \& Zhang 2009). General Motors misused its dominant position in the market to cancel and renegotiate existing contracts as well as demanding price concessions for upcoming seasons from suppliers. General Motors was exposed in pressurising suppliers for price deductions, non-cost-related payments or discounts, prolonged payment terms, warranty periods and questionable annexation of intellectual property and innovations.

It can therefore be concluded that power struggles do occur in supply chains. These relationships are often to the disadvantage of one party, who may not have the necessary resources or capabilities to counteract the actions of dominant supply chain players. Yet, the topic of immoral buying practices within buyer-supplier relationships has been neglected in scholar research (Schleper et al. 2015).

The problem is that dominant behaviour in supply chains is a common occurrence but is rarely reported on. Such behaviour negatively affects the optimal performance of a supply chain.

The study explores the global existence of dominant supply chain behaviour and the type of dominant supply chain practices to which smaller supply chain affiliates are subjected. Moreover, it identifies whether these practices are broad and across multiple business sectors or specific to certain industries.

\section{Research strategy}

Supply chain dominance was analysed by investigating previous incidents of dominance, bullying and resented practices by a firm or competing firms across several industries such as retail, automotive and manufacturing as reported in the media. Secondary data sources were analysed
BOX 1: Keywords utilised in data searches and to filter data into codes.

\begin{tabular}{|l|l|}
\hline - Supply chain dominance & - Ethical business relationships \\
- Supply chain bullying & Buyer-supplier relationships \\
- Supply chain challenges & - Supplomer relationship management \\
- Supply chain power & - Unethical business practices \\
- Competitive supply chains & - Business contract manipulation \\
- Dominant influences of buyers & - Buyer and seller manipulation \\
- Dominant influences of suppliers & - Resented business practices \\
- Power influences in supply chains & - Supply chain relation issues \\
- Business bullying & - Supply chain disputes \\
- Business dominance & - Supplier collusion \\
- Business power & - Supply chain connectivity \\
- Dominant business relationships & - Moral aspect of business practices \\
- Exploitation of buyers & - Supply chain dependency \\
- Exploitation of suppliers & - Abuse of dominance \\
- Competitive advantage & - Competition \\
- Monopolistic characteristics & - Anti-competition \\
- Power & - Competition law \\
- Ruthorities & - Competition policy \\
\hline
\end{tabular}

using a thematic analytical approach (Saunders Lewis \& Thornhill 2016). From an extensive literature search, covering a 15-year period (2003-2017), using 38 keywords (Box 1), multiple sources were identified and evaluated for relevance. The final list of relevant sources included 12 books, 13 journal articles, five academic reports and 29 websites which consisted of media articles, media reports, E-books, E-magazines, government publications as well as E-newspapers. The 38 keywords identified concepts relevant to dominance in the supply chain and were used to code the texts. The coded data were grouped into categories and then organised into themes, by developing codes, categories and themes, allowed for the quantising of the qualitative data.

\section{Ethical considerations}

Ethical clearance was obtained from the Department of Transport and Supply Chain Management to conduct this secondary research (number: FOM2017-TSCM013).

\section{Results}

\section{Theme 1: Geographic occurrence of reported supply chain dominance cases}

By quantitising the qualitative data, the incidences of reported dominance across all regions of the world could be determined (Figure 1).

It seems that developed countries report dominance more frequently compared to less economically developed countries (Figure 1). Of the 60 cases of dominance, Europe had the highest number of cases of dominance (34\%) reported, followed by North America (32\% of cases). Far fewer cases were reported in other regions with $10 \%$ of cases of dominance from Africa, while only $8 \%$ each were from Asia, Australasia and South America.

These results support the UNCTAD (2008) finding that, in developed countries, more resources are utilised towards governing and monitoring markets to ensure that fair competition occurs as well as to negate anti-competitive practices (UNCTAD 2008). Thus, these developed regions have the appropriate authorities, policies and procedures in place to properly enforce such monitorisation (UNCTAD 2008). This explains why the majority of supply chain 


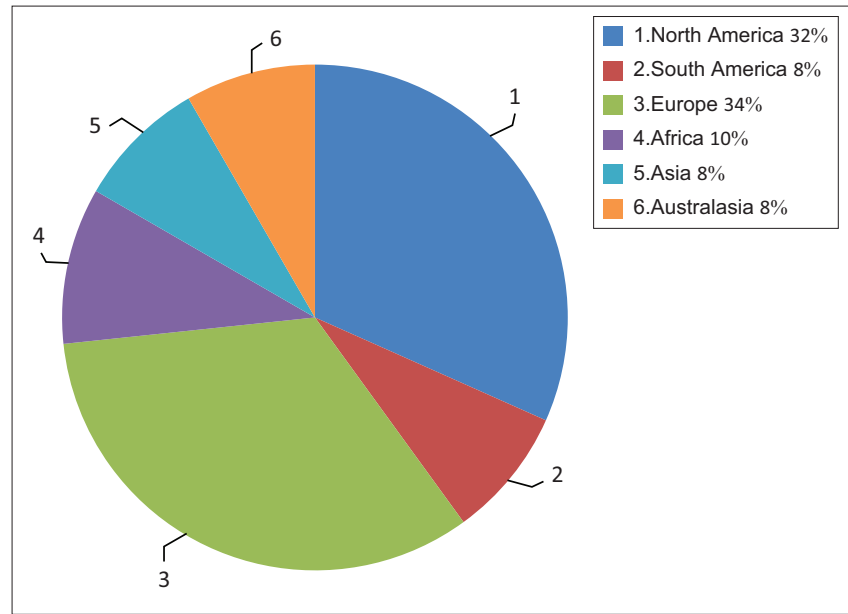

FIGURE 1: Geographic occurrence of reported supply chain dominance.

dominance cases were reported in developed regions of the world. Although in developing countries and regions of the world, there may actually be more incidences of supply chain dominance occurring, these are not being reported because of the lack of authoritative entities governing markets.

However, in developing countries, abuse of supply chain dominance is a major concern. In these countries, because of underdeveloped infrastructure and weak economies, multinational firms with their superior efficiency tend to develop into monopolies (UNCTAD 2008). This practice, along with the formation of cartels, can severely harm businesses and consumers as the products and services offered by these dominant firms are subject to anticompetitive practices that block access to markets, in addition to raising prices (UNCTAD 2008).

\section{Theme 2: Types of resented practices}

Only three broad categories of resented practices were identified as being utilised by dominant firms. Of the 60 implemented resented practices, 63\% were financial in nature, as dominant firms mostly utilised pay-to-stay, longterm payments, late payment, prompt payment discounts and respective discounting (Green 2014). These practices appear to be the easiest to manipulate for profitability gains or cost-saving margins in both short- and long-term periods (Giroux 2008). However, such practices have drastic consequences for affected firms, with reports stipulating that such practices may cause 'bullied' firms to close down (Baruch 2016).

Furthermore, exclusionary and exploitive practices jointly represent over a third (37\%) of utilised resented practices. These practices are more difficult to implement as their implementation requires the dominant firm to hold a monopolistic position within the market or a majority market share in a competitive market (UNCTAD 2008). Thus, such practices are more likely to be implemented by multinational firms with the appropriate resources and market share to achieve such major dominant positions.

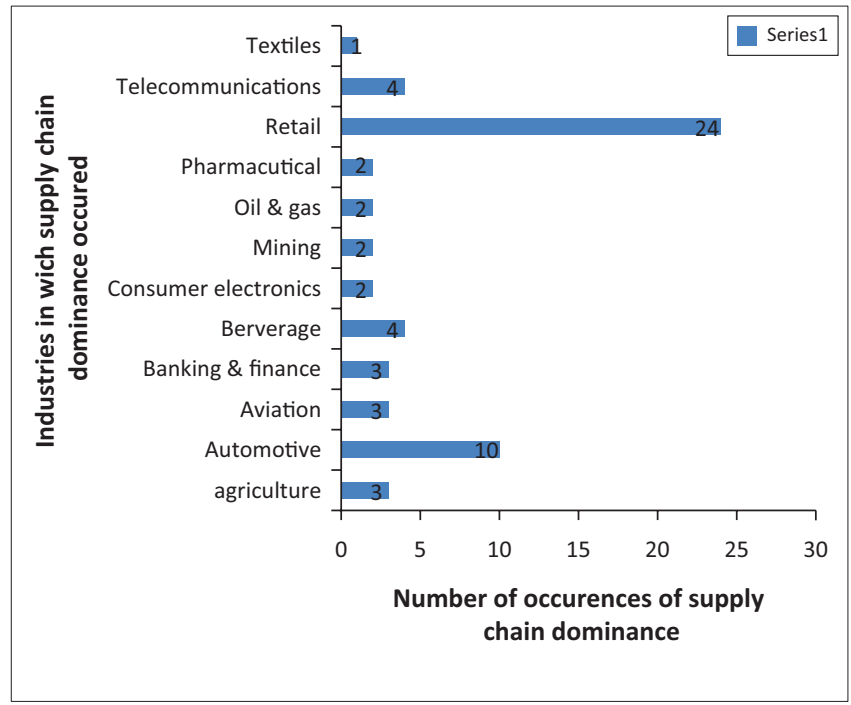

FIGURE 2: Industry specific occurrences of supply chain dominance.

\section{Theme 3: Industries where dominance occurs}

From the results in Figure 2, the largest percentage (40\%) of dominance cases was reported in the retail sector, followed by the automotive sector (17\%).

It is apparent that dominant behaviours have diffused among various sectors, from the agricultural sector, consumer electronics market, to the textiles industry, suggesting that no market is immune to such practices. Such distribution of bullying behaviour is problematic for authoritative entities, as each market has varying acceptances of such behaviours (UNCTAD 2008).

Additionally, these findings suggest that the implementation of resented practices is growing and may be because of the evolution of the product life cycles into shorter and leaner series as increased globalisation is introducing more competition into markets (Calantone et al. 2010). Thus, firms need to release new products and services continuously to stay ahead of the competition as well as to maintain profits and market share (Calantone et al. 2010). Furthermore, such fast-paced product introduction has resulted in consumers becoming more accustomed to increased variety and updated products, making it a necessity for firms to achieve this (Calantone et al. 2010). Thus, dominant firms implement these behaviours to ensure that their new products and services survive and thrive in competitive markets by increasing profit margins, reducing costs and competition, thereby making their products and service more affordable for consumers (Calantone et al. 2010). This could explain why the retail industry accounts for $40 \%$ of industry specific dominance occurrences.

\section{Theme 4: Dominant behaviours and small businesses}

From these findings, it is evident that supply chain dominance occurs globally. It is a major concern for small- and mediumsized enterprises (SMEs) as they represent the majority of victimised firms, because of their high vulnerability to 
resented practices, in addition to other market pressures such as economic, political, legal or environmental issues (OECD 2003). Small- and medium-sized enterprises have limited access to resources such as capital, finance, assets and employees, which restrict their ability to withstand, negate or overcome enforced resented practices (OECD 2017).

The identification of dominance can be problematic as the distinction between unethical dominant behaviour and strong market dominance is not clear. Both behaviours display similar attributes with only a few key differences. In addition, the guidelines set up by governing authorities to differentiate between these types of behaviour differ from country to country, with each nation having their own specific descriptions (UNCTAD 2008).

\section{Conclusion}

Successful supply chains no longer exist in silos but rather in an integrated and coordinated chain, with greater emphasis on the management of relationships among supply chain members (Mocke et al. 2016). Relationships within a supply chain are a source of competitive advantage by utilising a pull system, incorporating aspects of JIT delivery. This results in the right product or service of the right quality being delivered at the right time in the right place at the right price. Relationship connectivity allows members of the supply chain to compete successfully while simultaneously dealing with changes in technology, globalisation and the economic landscape. Trust between members of the supply chain is essential to gain a level of equity and satisfaction (Hines \& Samuel 2004). However, business relationships can lead to dominance between organisations and their suppliers. Power is often found at the core of business relationships whereby their practices are seen as unethical with one organisation exerting their dominance over another firm.

Supply chain dominance has gained the attention of the media, resulting in more exposure of the topic, whereby smaller firms have been subjected to dominant practices by larger firms. Supply chain bullying seems to be a growing trend in the supply chain and refers to a participant in the supply chain having an influence over other members operating within the same supply chain. Dominance is experienced in the supply chain through three categories of practices which include financial, exclusionary and exploitative (Green 2014). From an analysis of the 60 reported cases, financial practices were the major contributor to supply chain dominances whereby late payments and pay-to-stay practices were utilised by large firms to control costs, product quality and relationships between small suppliers and the firm. These types of practices were highlighted by Ruddick (2014). Late payments occurred by increasing the payment period of suppliers, while simultaneously requesting continuous deliveries of goods and services. Suppliers also faced pay-to-stay practices whereby they were indirectly forced to pay the larger firms in order to maintain their supplier superiority and viability of their operations.
This created major problems for suppliers as it affected their cash flows and ultimately affected their profits (Steiner 2015). Reported cases predominantly occurred in the United States and Europe, with fewer cases being reported in Africa, Asia and South America. The reason for the lack in reporting can be because of the lack of infrastructure and weak economies, limiting their ability to report cases of dominant practices by large firms (UNCTAD 2008). From the reported cases, it follows that industries such as retail, automotive, banking and beverages have experienced several cases of dominance. A report issued by the FSB stated that one out of five SMEs is a victim of dominance with cases being reported from suppliers of Heinz, Tesco, Marks and Spencer as well as Premier Foods and AbInBev (Matthews 2014).

Dominance that occurs between firms and their suppliers may have a negative impact on the overall functioning and viability of the relationship, which may affect the operations of the supply chain. Supply chain dominance seems to be evident that it is occurring in several regions of the world across several different industries. However, strict laws and policies have failed to control the domination of suppliers by large firms, resulting in the practices spreading to several other industries and regions of the globe.

\section{Management implications}

Supply chain dominance is said to be damaging the operations and fundamental practices of suppliers and organisations operating within the supply chain. Resented practices such as late payments are a major contributor to dominance and bullying among supply chain partners; however, despite policies put in place, it is still widely occurring. The Prompt Payment Code implemented in the United Kingdom is an agreement by signatories to remunerate their suppliers within the agreed terms of the contract as well as ensuring that the correct action is followed when payment issues do arise. The media play an important role in exposing unethical dominant practices within supply chains as firms may face being 'named and shamed', ultimately affecting their image as well as their profits. Additionally, governmental authorities have an important role to play in order to monitor, control and eradicate dominance issues that may occur through the use of strict legislation and penalties for transgressions. However, financial payments must be utilised in conjunction with enforced policies in order to limit the domination of small businesses. A level playing field must be established, whereby the entire supply chain from end-to-end can benefit.

Supply chain dominance is a concept that needs further clarification and definition. It is still a novice notion that is being identified in supply chains throughout the world, and thus lacks the appropriate academic research to fully understand why such behaviours occur. In addition, a clear demarcation between fair and unfair business practices does not exist, which may contribute to underreporting. Hence, further primary research is critically needed in order to fully 
comprehend relations between suppliers and buyers in totality, as such academic research will provide a muchneeded insight into the negative side of supply chain dominance.

A limitation of the study is the highly sensitive nature of the topic, requiring a secondary data analysis rather than the collection of primary data to fully understand the extent and impact of dominance in the markets and its effect on small firms.

\section{Acknowledgements Competing interests}

The authors declare that they have no financial or personal relationships that may have inappropriately influenced them in writing this article.

\section{Authors' contributions}

All the authors made a substantial contribution to the conception and design of the multidisciplinary project. J.-M.D.Y. and B.T. did the literature review and sourced and analysed the data. All the authors were involved in the interpretation of data. E.S. drafted the manuscript, and S.G.N and E.S. critically revised it for important intellectual content and approved the final version to be published.

\section{Funding information}

No grants or other forms of support were received to conduct the work described in the article or the writing of the article itself.

\section{Data availability statement}

Data sharing is not applicable to this article as no new data were created or analysed in this study.

\section{Disclaimer}

The views expressed in this article are the authors' own and do not reflect an official position of the University of Johannesburg.

\section{References}

Agence France-Presse, 2017, Renault targeted in new 'dieselgate' scandal, viewed 01 April2017,from, http://www.livemint.com/Politics/apY33TewqEAIAAJ1jTJ9JM/ Renault-targeted-in-new-dieselgate-scandal.html.

Akhtar, P. \& Khan, Z., 2015, 'The linkages between leadership approaches and coordination effectiveness', British Food Journal 117(1), 443-460. https://doi. org/10.1108/BFJ-12-2013-0357

Arshinder, K., Kanda, A. \& Deshmukh, S.G., 2011, 'A review on supply chain coordination: Coordination mechanisms, managing uncertainty and research directions', in T. Choi \& T.E. Cheng (eds.), Supply chain coordination under uncertainty, 39-82, Springer-Verlag, New Delhi.

Axis Telecoms, 2014, FSB raises concerns over 'supply chain bullying' of SMEs, viewed 16 March 2017, from http://axistelecomnews.co.uk/fsb-raises-concerns-oversupply-chain-bullying-of-smes/.

Babilonia, L.G., n.d., Dominant retailer's roles in supply chain, s.n., s.I.

Barber, E., 2011, 'Strategic approaches to domination in supply chains', in S. Renko (ed.), Supply chain management - New perspectives, Intech, Rijeka.
Baruch, B., 2016, Time to act: The economic impact of poor payment practice, viewed 03 August 2017 from http://www.fsb.org.uk/docs/default-source/fsb-org-uk/fsbreport---late-payments-2016-(final).pdf.

Benton, W.C. \& Maloni, M., 2005, 'The influence of power driven buyer/seller relationships on supply chain satisfaction', Operations Management 23(1), 1-22. https://doi.org/10.1016/j.jom.2004.09.002

Berlin, D.C., 2017, Supplier joins VW in hot seat over emissions scandal in US, viewed 10 March 2017, from http://go.galegroup.com/ps/i.do?p=AONE\&sw=w\&u=rau it $w \& v=2.1 \& i d=G A L E \% 7 C A 479715781 \& i t=r \& a s i d=9809 c 5 a 912 b 35407 \mathrm{db} 93 a b 9 \bar{d} b$ $2 \mathrm{e} 81677$.

Beske, P., Land, A. \& Seuring, S., 2014, 'Sustainable supply chain management practices and dynamic capabilities in the food industry: A critical analysis of the literature', Production Economics 152, 131-143. https://doi.org/10.1016/j. ijpe.2013.12.026

Breen, B., 2004, Living in Dell Time, viewed 17 March 2017, from https://www. fastcompany.com/51967/living-dell-time.

British Institute of Facilities Management, 2015, Supply chain relationship management, BIFM, Hertfordshire.

Burt, D.N., Dobler, D.W. \& Starling, S., 2003, 'Buyer-supplier relationships', in World class supply management, pp. 79-99, McGraw-Hill, s.I.

Calantone, R.J., Yeniyurt, S., Townsend, J.D. \& Schmidt, J.B., 2010, 'The effects of competition in short product life-cycle markets: The case of motion pictures', Journal of Product Innovation Management 27(3), 349-361. https://doi. Journal of Product Innovation Man
org/10.1111/j.1540-5885.2010.00721.x

Cavano, K., 2015, Clamping down on late payments and supply chain bullies, viewed 17 March 2017, from http://businessadvice.co.uk/supply-chain/international/ clamping-down-on-late-payments-and-supply-chain-bullies/.

Coyle, J.J., Langley Jr, C.J., Novack, R.A. \& Gibson, B.J., 2013, 'Supply chain relationships', in Managing supply chains: A logistics approach, 115, Cengage, Boston, MA.

Crotty, A., 2017, 'Rooibos Limited guilty of abuse of dominance', Business Day, 20 June.

Deci, E.L. \& Ryan, R.M., 2014, 'Autonomy and need satisfaction in close relationships: Relationships motivation theory', in Human motivation and interpersona relationships, 53-73, Springer, New York.

Euler Hermes, 2017, Global sector report: Automotive, Euler Hermes, Paris.

Giroux, G., 2008, 'What went wrong? Accounting fraud and lessons from the recent scandals', Journal of Social Research 75(4), 1205-1238.

Green, W., 2014, Supply chain bullying' hits almost one in five small firms, viewed 26 February 2017, from https://www.cips.org/supply-management/news/2014/ december/supply-chain-bullying-hits-almost-one-in-five-small-firms/.

Henke, Jr, J.W., Yeniyurt, S. \& Zhang, C., 2009, 'Supplier price concessions: A longitudinal empirical study', Marketing Letters 20(1), 61-74. https://doi. org/10.1007/s11002-008-9034-5

Hines, P. \& Samuel, D., 2004, Development of supply chain relationships: A multi-lens approach, viewed 03 March 2017, from http://sapartners. com/wp-content/uploads/2012/08/The-Development-of-Supply-ChainRelationships.pdf.

Institute of Business Ethics, 2013, Supply chain and payment practices, IBE, London.

International Fund for Agriculture Development, 2013, The power of partnerships: Forging alliances for sustainable smallholder agriculture, International Fund for Agriculture Development, Rome.

Keyton, J., 2010, 'Introduction to qualitative research', in Communication research, 63-79, McGraw-Hill, Glasgow.

Kolb, B., 2008, 'Conducting secondary research', in Marketing research, pp. 86-90, Sage, s.l.

Li, S., Ragu-Nathan, B., Ragu-Nathan, T.S. \& Rao, S.S., 2006, 'The impact of supply chain management practices on competitive advantage and organizational performance', Omega 34, 107-124. https://doi.org/10.1016/j.omega.2004. 08.002

Mail Online, 2017, VW pleads guilty to US criminal charges, pays $\$ 4.3 b n$ in 'dieselgate' viewed 01 April 2017, from http://www.dailymail.co.uk/wires/afp/ article-4110618/VW-pleads-guilty-US-criminal-charges-pays-4-3-bn-dieselgate. html.

Matthews, D., 2014, Small suppliers being bullied by big customers - FSB, viewed 16 March 2017, from http://minutehack.com/news/small-suppliers-beingbullied-by-big-customers-fsb.

Mayer, R., 2007, 'What is wrong with exploitation?', Applied Philosophy 24(2), $137-150$.

Mocke, K., Niemann, W. \& Kotze, T., 2016, 'The role of personal relationships between buyers and suppliers of third-party logistics services: A South African perspective', Acta Commercii 16(1), 367. https://doi.org/10.4102/ac.v16i1.367

North Carolina State University, 2011, What is supply chain management, viewed 15 February 2017, from https://scm.ncsu.edu/scm-articles/article/what-issupply-chain-management.

OECD, 2003, How enforcement against private anticompetitive conduct has contributed to economic development, viewed 10 August 2017, from www.oecd. org/competition.

OECD, 2017, OECD economics surveys - South Africa, viewed 10 August 2017, from https://www.oecd.org/eco/surveys/2017-OECD-Economic-Survey-South-Africaoverview-2017.pdf. 
Raven, B.H., 2008, 'The bases of power and the power/interaction model of interpersonal influence', Analyses of Social Issues and Public Policy 8(1), 1-22.

Ruddick, G., 2014, One in five suppliers has been 'bullied' by large company, viewed 16 March 2017, from http://www.telegraph.co.uk/finance/newsbysector/retailand consumer/11286218/One-in-five-suppliers-has-been-bullied-by-large-company.htm.

Saunders, M., Lewis, P. \& Thornhill, A., 2016, Research methods for business students, Pearson, Harlow.

Schleper, M.C., Blome, C. \& Wuttke, D.A., 2015, 'The dark side of buyer power Supplier exploitation and the role of ethical climates', Journal of Business Ethics 140(1), 97-110. https://doi.org/10.1007/s10551-015-2681-6

Simpson, B., 2009, 'Wealth and income inequality: An economic and ethical analysis', Journal of Business Ethics 89(4), 525-527. https://doi.org/10.1007/s10551-0080014-8

Smith, C., 2015, SA's negative economic trend gains velocity, viewed 20 Augus 2017, from http://www.fin24.com/Economy/SAs-negative-economic-trend-gainsvelocity-economist-20151014.

Steiner, R., 2015, How the bully-boy banks and supermarkets conspire to rip off suppliers by delaying payment of loans if they can't wait for settlement, viewed 05 August 2017, from http://www.dailymail.co.uk/news/article-3015570/How-bullyboy-banks-supermarkets-conspire-rip-suppliers-delaying-payment-loans-t-waitsoy-banks-superm
Sunderland, R., 2015, The supply chain bullies: The giant household names that stand accused of hurting small suppliers, viewed 16 March 2017, from http://www. accused of hurting small suppliers, viewed 16 March 2017, from http://www. supply-chain-bullies-Big-firms-increase-payment-terms-small-suppliers.html.

Sweeney, E., 2011, 'Supply chain integration: Challenges and solution', in P. Evangelista (ed.), Innovation for competing in highly competitive markets: Challenges and solutions, s.n., Dublin.

The Drive, 2015a, Diesel-hacking Scandal Sends Volkswagen Reeling, viewed 16 March 2017, from http://www.thedrive.com/dieselgate/254/diesel-hacking-scandalsends-volkswagen-reeling.

UNCTAD, 2008, Abuse of Dominance, Trade and Development Board, Geneva.

Williams, C., 2015, Tesco faces fresh accusations of 'bullying' suppliers over price cuts, viewed 16 March 2017, from http://www.telegraph.co.uk/finance/newsbysector/ retailandconsumer/11399558/Tesco-faces-fresh-accusations-of-bullying suppliers-over-price-cuts.html.

Woiceshyn, J., 2011, 'A model for ethical decision making in business: Reasoning, intuition, and rational moral principles', Journal of Business Ethics 104(3), 311. https://doi.org/10.1007/s10551-011-0910-1

Zietsman, M. \& Coetser, P., 2017, Competition Commission can view exclusionary contracts as anticompetitive, viewed 01 September 2017, from http://www. bizcommunity.com/Article/196/739/160865.html. 